\title{
172. ヌードマウス移植可頭頸部癌および頭頸部癌
}

\section{培養株を用いた実験的化学療法}

\author{
宮田 守・西野 宏・中村良博・五十葻丈人・森田 守（自治医大）
}

ヌードマウス移植ヒト頭頸部扁平上皮癌株およびヒ 卜上顎扁平上皮癌培養株を用いて, $\mathrm{CDDP}+5-\mathrm{FU} の$

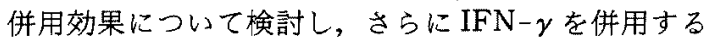
ことにより CDDP+5-FU の併用効果がどのように影 響されるかを検討した。

方法 ヌードマウス移植株 $(\mathrm{MC}-1$ : 上顎低分化扁 平上皮癌, $\mathrm{MC}-3$ : 上䫑高分化扁平上皮癌, $\mathrm{MPC}-1$ : 中咽頭低分化扁平上皮癌) を用いたヌードマウス皮下 移植法およびヒト上顎扁平上皮癌培養株 (MMSI-1) を用いた Human tumor clonogenic assay (H.T.C. A.)により検討した．1） ヌードマウス皮下移植法 薬 剤の投与量は，単独投与の場合は $\mathrm{LD}_{50} / 3$ を 4 日毎に 3 回腹腔内に投与し, 併用投与の場合は $\mathrm{LD}_{50} \times 0.6 / 3$ を同様に腹空内に投与した. IFN- $\gamma$ については, 単独 投与の場合は $4 \times 10^{6} \mathrm{U} / \mathrm{Kg} /$ 回とし，併用投与の場合は $2.4 \times 10^{6} \mathrm{U} / \mathrm{Kg} /$ 回とし，腹腔内投与と腫湯内投与を行 った. 効果判定は Battle Columbus Laboratories Protocol に準じて行った，2）H.T.C.A. 井上らの方 法に準じて行った。薬剤の接触時間は，1時間接触と 2 週間の持続接触とし，効果判定は対照群に対して50 \%以上のコロニー形成阻止率を示したものを効果 $(+)$ とした．各薬剤の使用量は，CDDP $0.2 \mu \mathrm{g} / \mathrm{ml}, 5-\mathrm{FU}$ $1 \mu \mathrm{g} / \mathrm{ml}, \mathrm{IFN}-\gamma$ は $10^{2} \mathrm{U} / \mathrm{ml}, 10^{3} \mathrm{U} / \mathrm{ml}, 10^{4} \mathrm{U} / \mathrm{ml}$ の 3 段階とした.

結果 1) ヌードマウス皮下移植法 MC-1: 5-FU 単純投与 (効果 -$), \mathrm{CDDP}(+), \mathrm{CDDP}+5-\mathrm{FU}$ 併用 $(+), \mathrm{CDDP}+5-\mathrm{FU}+\mathrm{IFN}-\gamma($ i.p. $)(++), \mathrm{CDDP}+$ $5-\mathrm{FU}+\mathrm{IFN}-\gamma($ i.t. $)(++)$. MC-3: 5-FU $(-)$, IFN $-\gamma(-), \mathrm{CDDP}+5-\mathrm{FU}(-), \mathrm{CDDP}+5-\mathrm{FU}+\mathrm{IFN}-$ $\gamma$ (i.p.) (-), $\mathrm{CDDP}+5-\mathrm{FU}+\mathrm{IFN}-\gamma$ (i.t.) $(++)$. $\mathrm{MPC}-1: 5-\mathrm{FU}(-), \operatorname{CDDP}(-), \mathrm{CDDP}+5-\mathrm{FU}(+)$ であった. $\mathrm{CDDP}+5-\mathrm{FU}$ の併用効果は, MC-1, MPC
-1 においては重相加作用, MC-3 では干涉作用であっ た， $\mathrm{MC}-3$ の CDDP +5-FU の併用効果に対就 IFN 一 $\gamma$ (i.t.)の効果は相乗作用であった. 2) H.T.C.A. 各 薬剤単独群におりる効果は，1 時間接触では CDDP の みが効果 $(+)$ であり, 持続接触では, 5-FU, CDDP, IFN $-\gamma\left(10^{3} \mathrm{U} / \mathrm{ml}\right)$, IFN $-\gamma\left(10^{4} \mathrm{U} / \mathrm{ml}\right)$ がそれぞれ効 果 $(+)$ であった。併用効果については, CDDP+5-FU, $\mathrm{CDDP}+5-\mathrm{FU}+\mathrm{IFN}-\gamma\left(10^{2} \mathrm{U} / \mathrm{ml}, 10^{3} \mathrm{U} / \mathrm{ml}, 10^{4} \mathrm{U} /\right.$ $\mathrm{ml})$ すべての群で効果 $(+)$ であった. $\mathrm{CDDP}+5-\mathrm{FU}$ の併用効果は亜相加作用であり，また持続接触に扑い $\tau, \mathrm{CDDP}+5-\mathrm{FU}$ の併用に高濃度の IFN $-\gamma$ を作用さ せると強いコロニー抑制効果が認められた。

まとめ 1) ヌードマウス移植株に対するCDDP+ 5-FU の併用効果は，3株中 2 株に扔いて亜相加作用 を示し，他の1株では千渉作用を示した，2）MC-1て は，IFN- $\gamma$ の腹腔内投与抢よび腫場内投与両群ともに $\mathrm{CDDP}+5-\mathrm{FU}$ の抗腫煌効果の増強が認められた。 た各種薬剈に抵抗性を示した MC-3では, IFN- $\gamma$ を 直接腫湯内に投与することによって CDDP+5-FUに 対する感受性の六進 (相乗作用) が認められた。 3) 卜上顎扁平上皮癌培養細胞を用いた H.T.C.A.におい て, CDDP $+5-\mathrm{FU}$ の併用効果は要相加作用であっ た. また持続接触において, CDDP+5-FU の併用に高 濃度の IFN $-\boldsymbol{y}$ を作用させると強いコロニー抑制効果 が認められた。質問 武田哲男(獨協医大).1) 又 ードマウスへの腫演生着率は，どのぐらいだったか。

2）腫湯をつくってから何日ぐらいで化学療法を開始 したか。応答 1）腫湯移植後の生着率は長期間 察すると 9 割以上と思われた。2）腫瘍移植後, 腫場の 推定重量が $100 \sim 300 \mathrm{~g}$ となった時点で実験を開始し た。

\section{3. 頭頸部癌におけるCisplatin-Peplomycin 療法} に対する Second Line Chemotherapy の検討

\author{
川浦光弘・田中一仁・田路正夫 - 藤井正人 - 田中寿一・高岡哲郎 - 細田兵之助 \\ 川谷敦子・川崎和子・神崎 仁（慶大）犬山征夫（北大）
}

CDDPは頭頸部癌において有効性が高く，当科にお いても PEP との併用療法では奏効率 $68 \%, \mathrm{CR}$ 率 $26 \%$ との結果を得ている。しかし，再発する症例も少なく なく，臨床において CDDP-PEP 療法施行後の再発に 対する Second Line Chemotherapyに有効著剂があ まりないため，その選択に困る時がしばしばある。我々 は CDDP-PEP 療法に対するSecond Line Chemo- therapy の決定のため in vitro でヒト口腔底癌由来の $\mathrm{KB}$ 細胞の培養株を用いて, CDDP と PEP 以外で顓頸 部癌によく用いられるVDS, ADR, MMC, MTX, 5-FU から二者併用群全10通りの効果をChou らによ る median effect equation にて分析し，さらにその中 で相乗効果のあったものに対し colony formation assayで効果を確認した. 
方法は, ヒト口腔底癌由来の $\mathrm{KB}$ 細胞を 96 wellplate $の$ 各 well に播き, 約 24 時間, $37^{\circ} \mathrm{C}, 5 \% \mathrm{CO}_{2}$ イ シキュベーター内で培養したのち, 薬剤を添加し， 5 日後に0.5\%メチレンブルーで染色し,その吸光度を測 定し增殖阻害率を求めた。先述した 5 薬剤の単剂と二 者併用群の増殖阻害率を median effect equation にて microcomputer system を使って分析した。この式は Chouらによって報告されたもので，2つの薬戍が一 定の比率で併用された場合, それらが相乗的, 相加的, 拮抗的に働くかを求めたものである。

その結果, ADR + MMCは弱い相乗効果が 5-FU+ MMCには強い相乗効果がみられた。ささらにこの二通 りの二者併用を colony formation assayでその効果 を確認した. 方法は, $\mathrm{KB}$ 細胞を $\phi 60 \mathrm{~mm}$ のシャーレに 播き，約72時間, $37^{\circ} \mathrm{C}, 5 \% \mathrm{CO}_{2}$ インキュベーター内 て培養したのち薬剤を 24 時間接触させ，10日後に形成
した colony をカウントし, surviving fraction (以下 S.F.)を求めた。この場合, ADR と 5-FU の濃度を固 定して MMC の濃度を変化させ, MMC 単剤のS.F.と ADR と 5-FU の S.F.を単純に加算したところを相乗 効果があるとみなし，併用のS.F.がそれより効果が見 られた場合相乗効果があるとし，見られなければ拮抗。 作用があるとした。その結果, ADR+MMC 蛙拮抗作 用がみられ，5-FU+MMC は相乗効果がみられた。最 後に当科において KB 細胞を CDDPに持続的に作用 させて stepwise selection methodにて作製した CDDP 而性 KB 細胞に対し同様の方法で colony formation assay でこの 5-FU+MMCの効果を試したと ころ, 相乗効果を示した。 以上の結果ょり 5-FU+ MMC は CDDP - PEP 療法に対するSecond Line Chemotherapy として有用であると考えた。

\section{EB ウイルス感染による上皮細胞の腫瘍原性}

\section{滰元 徹・田中佐一良・石川 滋・桝田 耕・吉崎智一・西村俊郎・梅田良三（金沢大）}

目的 我乃は以前に, in vitroの実験において,アデ ノイド由来の上皮細胞とリンパ芽球様細胞との樹立化 に成功し，センダイウイルスを用いた細胞融合法を用 いて EBV ゲノム保有上皮系雑種細胞 $(\mathrm{A} 2 \mathrm{~L} / \mathrm{AH})$ を作 ることに成功した。この樹立後早期（継代培責30代ま て）の A2L/AH 細胞はヌードマウスに移植が困難で あったが,さらに長期にわたり継代培養することによ クヌードマウスに移植可能となった，今回，この樹立 後早期の A2L/AH 細胞をクローニングし, EBV グ， 厶陽性並び陰性 A2L/AH 細胞クローンを作り長期 培養し、ヌードマウスへの可移植性を比較検討したの でここに報告した。

方法と材料 使用細胞とクローニング：保存用液体 窒素容器加早期継代培養代数の $\mathrm{A} 2 \mathrm{~L} / \mathrm{AH}$ 細胞をも と゚し10\%牛胎児血清加 Eagle 培地を用いて培養を行 った，その後，マイクロプレートを用いて，細胞のク
ローニングを行った。ヌードマウス：ヌードマウスは BALB/C (nu/nu) SIc の6-8 週齢のメスを使用し た.

結果と考察 我々は, 1 つの EBV ゲノム陰性の $\mathrm{A} 2 \mathrm{~L} / \mathrm{AH}$ クローン (cl-654) と数多くの EBVゲノム 陽性の A2L/AH クローンを作ることに成功した。こ れらの細胞を長期継代培養し，ヌードマウスへの移植 性を調へたた. EBV ゲノム陽性細胞は，以前に報告した 親細胞である A2L/AH 細胞と同様に継代培養 30 代以 降においてヌードマウスへの腫腸原性を獲得した。一 方, EBV ゲノム陰性細胞は，長期継代培養にもかかわ らずヌードマウスへの腫慯原性を獲得することは不可 能であった。この実験的研究より, EBVは上皮細胞に おいて EBV ゲノムを長期維持することにより腫瘍原 性を獲得する可能性を示している。

\section{Epstein-Barr virus 感染早期抗原と細胞融合}

\section{竹下 元・古川 仍・坂下英雄・梅田良三（金沢大）}

目的 Epstein-Barr virus (EBV) は細胞融合能を 持ったウイルスであり, 細胞融合には EBV 感染早期 蛋白が関与することが, Baylissらの EBV 重感染 Raji 細胞を用いた実験において訨明されている. 今回 上咽頭癌モデル細胞を用いて, 細胞融合への EBV 感 染早期抗原の関与について実験的検討を加えたので報 告した.

方法 上皮系細胞として A2L/AH 細胞, Ad 細胞.
浮遊系細胞として P3HR-1 細胞，Raji 細胞を用いた。 EBV関連抗原誘発郕として TPA (12-0tetradecanoylphorbol-13-acetate), n-butyrate 核酸合成阻害剤としてAra-C (cytosine arabinoside), 蛋白合成阻害剂として $\mathrm{CH}$ (cycloheximide)を用いた。重感染用のウイルスは P3HR-1 細胞 培養上清液加ら抽出し前述の細胞に感染させた。 Raji 細胞では融合細胞を形態学的に観察するために, Ken- 